\title{
Total cholesterol/HDL cholesterol ratio and monocyte/HDL cholesterol ratio are related with subclinical hypothyroidism in polycystic ovary syndrome
}

\section{Total kolesterol/HDL kolesterol oranı ve monosit/ HDL kolesterol oranı polikistik over sendromunda subklinik hipotiroidi ile ilişkilidir}

https://doi.org/10.1515/tjb-2021-0050

Received March 4, 2021; accepted August 11, 2021; published online September 3, 2021

\section{Abstract}

Objectives: There is an association between serum thyrotropin (TSH) and lipid profile. However, there is a little information regarding the relation between subclinical hypothyroidism (SCH), atherogenic indices and inflammation in polycystic ovary syndrome (PCOS). Herein, we aimed to evaluate the impact of $\mathrm{SCH}$ on lipids and inflammatory markers in newly diagnosed PCOS patients.

Methods: Two groups were performed for total 99 PCOS patients: $\mathrm{SCH}(\mathrm{TSH}>2.5 \mathrm{mIU} / \mathrm{L})$ and euthyroid groups (TSH $<2.5 \mathrm{mIU} / \mathrm{L}$ ). Complete blood count, lipids, atherogenic indices were evaluated, inflammatory markers as platelet/ lymphocyte ratio (PLR), neutrophil/lymphocyte ratio (NLR), monocyte/high density lipoprotein ratio (MHR) and mean platelet volume/platelet ratio (MPR) were calculated.

Results: SCH group had higher WBC, PLT, PCT, PLR, MPR and non-high density lipoprotein cholesterol levels. Differences between MHR, total cholesterol/HDL cholesterol (TC/HDL), triglycerides/HDL cholesterol (TG/HDL) and low density lipoprotein/HDL cholesterol (LDL/HDL) levels

*Corresponding author: Isil Cakir, TC Saglik Bakanligi Kayseri Egitim ve Arastirma Hastanesi, 38010, Kayseri, Turkey,

E-mail: isilscakir@gmail.com. https://orcid.org/0000-0001-5728-

4671

Yasin Simsek, TC Saglik Bakanligi Kayseri Egitim ve Arastirma Hastanesi, Kayseri, Turkey. https://orcid.org/0000-0003-1654-6422 were significantly higher $(\mathrm{p}=0.001 ; 0.01 ; 0.01 ; 0.02$, respectively), TC/HDL cholesterol levels were positively correlated with TSH $(p=0.028, r=0.402)$ in $\mathrm{SCH}$ group. TC/ HDL levels were also correlated with WBC, PLT, PDW, PCT, MPR and MHR ( $\mathrm{p}=0.003 ; 0.011 ; 0.031 ; 0.037 ; 0.006 ; 0.002$; $\mathrm{r}=0.515 ; 0.442 ;-0.382 ; 0.370 ;-0.471 ; 0.523$, repectively). Conclusions: TC/HDL and MHR may serve as beneficial markers for evaluating the inflammatory state of PCOS with $\mathrm{SCH}$. Screening thyroid hormones and curing SCH in PCOS may lower lipids, decelerate developing hypothyroidism and cardiovascular morbidities.

Keywords: atherogenic markers; inflammation; monocyte to HDL ratio; polycystic ovary syndrome; subclinical hypothyroidism.

Öz

Amaç: Serum tirotropin (TSH) ve lipid profili arasında bir ilişki mevcuttur. Ancak, polikistik over sendromunda (PCOS) subklinik hipotiroidizm (SCH), aterojenik indeksler ve enflamasyon ile ilgili az sayıda bilgi bulunmaktadır. Burada, yeni tanı almış PCOS hastalarında lipidler ve enflamasyon belirteçleri üzerine SCH'nın etkisini değerlendirmeyi amaçladık.

Gereç ve Yöntem: Toplam 99 PCOS hastası için iki grup oluşturuldu: $\mathrm{SCH} \quad(\mathrm{TSH}>2.5 \mathrm{mIU} / \mathrm{L})$ ve ötiroid grup $(\mathrm{TSH}<2.5 \mathrm{mIU} / \mathrm{L})$. Tam kan sayımı, lipidler, aterojenik indeksler ve enflamasyon belirteçleri değerlendirildi.

Bulgular: SCH grubunda WBC, PLT, PCT, platelet/lenfosit oranı (PLR), monosit/platelet oranı (MPR) ve yüksek 
dansiteli lipoprotein kolesterol harici lipidlerin düzeyleri daha yüksekti.

Monosit/HDL kolesterol oranı (MHR), total kolesterol/ HDL kolesterol oranı (TC/HDL), trigliserid/HDL kolesterol (TG/HDL) ve düşük dansiteli lipoprotein/HDL kolesterol (LDL/HDL) düzeyleri $\mathrm{SCH}$ grubunda belirgin olarak daha yüksekti ( $\mathrm{p}=0.001 ; 0.01 ; 0.01 ; 0.02$;sırasiyla). SCH grubunda, TC/HDL kolesterol düzeyleri TSH düzeyleri ile pozitif olarak korele idi $(\mathrm{p}=0.028, \mathrm{r}=0.402)$. TC/HDL düzeyleri ayrıca WBC, PLT, PDW, PCT, MPR ve MHR düzeyleri ile de korele idi $(\mathrm{p}=0.003 ; 0.011 ; 0.031 ; 0.037$; $0.006 ; 0.002 ; \mathrm{r}=0.515 ; 0.442 ;-0.382 ; 0.370 ;-0.471$; 0.523 ;sırasıyla). ROC eğrisi analizine göre MHR, SCH görülen PCOS ile en fazla ilişkili enflamasyon belirteciydi (AUC:0.672; $\mathrm{r}=0.007$ )

Sonuç: TC/HDL ve MHR, SCH görülen PCOS için enflamatuvar durumun değerlendirilmesinde yararlı belirteçler olarak kullanılabilir. Tiroid hormonlarının araştırılması ve PCOS'de SCH'nin tedavi edilmesi lipidlerin düzeyini düşürebilir, gelişmekte olan hipotiroidizmi ve kardiyovasküler morbiditeleri geciktirebilir.

Anahtar kelimeler: aterojenik belirteçler; enflamasyon; monosit/ HDL oranı; polikistik over sendromu; subklinik hipotiroidizm.

\section{Introduction}

Polycystic ovary syndrome (PCOS) is a high frequent endocrinopathy affecting reproductive age women [1]. Its etiology is multifactorial and pathogenesis has completely unexplained. There are susceptible genes involving pathways of androgenesis and steroidogenesis. These genes are thought to be contributors to PCOS pathophysiology [2, 3]. As 'Androgen Excess and PCOS Society' defined, the diagnosis of the disease is based on (1) the presence of ovarian dysfunction signs as anovulatory oligomenorrhea causing menstrual disorders, (2) biochemical or clinical hyperandrogenism and (3) ultrasound proved polycystic ovaries [4]. Subclinical hypothyroidism (SCH) is defined as serum free thyroxine (fT4) levels are in reference interval, and thyrotropin (TSH) levels are above the reference range [5]. According to the study of Bedaiwy et al., we defined $\mathrm{SCH}$ as thyroid-stimulating hormone $>2.5 \mathrm{mIU} / \mathrm{L}$, and serum fT4 levels are in reference interval without symptoms of overt hypothyroidism [6].

SCH prevalence is higher in females, and $5-10 \%$ of PCOS patients have SCH $[7,8]$. SCH is an important clinical condition with the potential to develop into overt hypothyroidism [7]. In addition, especially in hypercholesterolemic postmenopausal women, $\mathrm{SCH}$ is a risk factor for myocardial infarction [9]. Emerging reports have shown the relation between thyroid functions and dyslipidemia in patients with PCOS [10-12]. Recent studies have also shown that lowgrade systemic chronic inflammation is related to PCOS pathogenesis [13]. To date, several inflammatory markers as interleukins (IL1a, IL1b, IL6, IL18 etc.), tumor necrosis factor- $\alpha$ (TNF- $\alpha$ ) or high sensitive C-reactive protein (CRP) have been investigated in patients with PCOS. Emerging studies also have assessed novel inflammatory markers in PCOS patients [13-15]. Another recent study was reported by Rudnicka et al. They compared PCOS patients with nonhyperandrogenic, normal-ovulating, age- and BMI-matched women peers and suggested in their study that low-grade chronic inflammation occurred in PCOS patients, and more specifically, those patients had statistically significantly higher WBC and CRP concentrations [16].

In our study, we aimed to evaluate $\mathrm{SCH}$ in our PCOS group. Also, we wanted to investigate the impact of $\mathrm{SCH}$ on lipid profile and inflammatory marker levels of PCOS patients.

\section{Materials and methods}

Our study included a total of 99 patients who were presented with complaints of clinical semptoms of PCOS at the endocrinology outpatient clinic between January 2017 and January 2018. The participants were newly diagnosed PCOS patients according to the Rotterdam criteria [17]. Their biochemical tests were evaluated. Patients group was divided into two subgroups according to TSH levels. 33 patients were formed SCH group having TSH $>2.5 \mathrm{mIU} / \mathrm{L}$ and 63 patients were formed euthyroid group having TSH<2.5 mIU/L. Patients' complete blood count parameters, including white blood cell (WBC), platelet (PLT) indices parameters as PLT, mean platelet volume (MPV), plateletcrit (PCT) and platelet distribution width (PDW), assessed using flow cytometry and fluorescent technologies by an automatized hematology analyzer Sysmex XN-1000 (Sysmex Corporation, Kobe, Japan) and other inflammatory markers as platelet to lymphocyte ratio (PLR), neutrophil to lymphocyte ratio (NLR), monocyte to high-density lipoprotein ratio (MHR) and mean platelet volume to platelet ratio (MPR) was calculated.

We recorded patients lipid parameters evaluated by colorimetric enzymatic assays [assessed by Olympus AU2700 autoanalyzer (Beckman Coulter, Tokyo, Japan] and calculated atherogenic indices as total cholesterol to high-density lipoprotein (TC/HDL) cholesterol ratio, triglycerides to HDL (TG/HDL) cholesterol ratio, low-density lipoprotein to HDL (LDL/HDL) cholesterol ratio and non-HDL cholesterol (TC- HDL cholesterol).

History of surgical operation of thyroid, hormonal replacement therapy, isotretinoin treatment, acute or chronic liver/renal disease and pregnancy were the exclusion criteria for patients.

Our study was performed in accordance with the Helsinki Declaration and Erciyes University Medical Faculty Ethical Committee approved the study protocol (2019/841). 
Table 1: Comparison of baseline characteristics and laboratory findings between two PCOS groups.

\begin{tabular}{|c|c|c|c|}
\hline & Group 1 (subclinical Hypothyroidism) & Group 2 (Euthyroidism) & p-Value \\
\hline Number of patients & 33 & 63 & - \\
\hline Age, years & $24.39 \pm 6.28$ & $23.92 \pm 5.86$ & 0.720 \\
\hline WBC $\left(4.5-10 \times 10^{3} / \mathrm{mm}^{3}\right)$ & $7.81 \pm 1.60$ & $7.68 \pm 1.74$ & 0.710 \\
\hline $\operatorname{PLT}\left(150-450 \times 10^{3} / \mathrm{mm}^{3}\right)$ & 331.1281 .84 & $315.11 \pm 68.49$ & 0.310 \\
\hline MPV (9-12 fL) & $10.39 \pm 1.19$ & $10.50 \pm 0.85$ & 0.590 \\
\hline РСТ (0.17-0.40\%) & $0.34 \pm 0.06$ & $0.33 \pm 0.06$ & 0.430 \\
\hline PDW (10-16 fL) & $12.50 \pm 2.38$ & $12.65 \pm 2.03$ & 0.740 \\
\hline PLR & $142.72 \pm 50.94$ & $134.20 \pm 35.75$ & 0.340 \\
\hline MHR & $0.014(0.010-0.017)$ & $0.010(0.009-0.013)$ & 0.007 \\
\hline MPR & $0.035 \pm 0.010$ & $0.034 \pm 0.013$ & 0.680 \\
\hline NLR & $1.74(1.30-2.47)$ & $1.63(1.33-2.23)$ & 0.032 \\
\hline TSH $(0.55-4.78 \mathrm{mIU} / \mathrm{L})$ & $2.78(2.51-3.44)$ & $1.66(1.17-2.37)$ & $<0.001$ \\
\hline fT4 $(0.54-1.24 \mathrm{ng} / \mathrm{dL})$ & $0.82 \pm 0.13$ & $0.89 \pm 0.17$ & 0.083 \\
\hline Total cholesterol/HDL cholesterol & $3.48(2.97-4.59)$ & $2.40(2.88-3.04)$ & 0.010 \\
\hline Triglycerides/HDL cholesterol & $2.34(1.75-4.10)$ & $1.87(1.26-2.77)$ & 0.010 \\
\hline LDL cholesterol/HDL cholesterol & $2.24 \pm 0.68$ & $1.92 \pm 0.56$ & 0.020 \\
\hline Non HDL cholesterol & $120.0 \pm 31.90$ & $116.48 \pm 28.07$ & 0.589 \\
\hline
\end{tabular}

WBC, White blood cell; PLT, platelet; MPV, mean platelet volume; PCT, plateletcrit; PDW, platelet distribution width; PLR, platelet to lymphocyte ratio; MHR, monocyte to high density lipoprotein ratio; MPR, monocyte to platelet ratio; NLR, neutrophyl to lymphocyte ratio; TSH, thyrotropin; fT4, free thyroxine. Student's $t$-test was used for group comparison; data were summarized as mean \pm SD. Mann-Whitney $U$ test was used; data were summarized as median and interquartile range (25-75\%). $p<0.05$, statistically significant.

\section{Statistical analysis}

We used SPSS software version 23.0 for Windows (SPSS Inc., USA) for statistical analyses. We performed the Kolmogorov-Smirnov test to assess the distribution of biochemical, hematological and hormonal parameters. We used Student's $t$-test to compare variables with normal distribution. We compared non-normally distributed variables with the Mann-Whitney $U$ test. We presented normally distributed, continuous variables by mean \pm standard deviation (SD), and nonnormally distributed, continuous variables by the median and interquartile range (25-75\%). Spearman's correlation coefficients were used to assess the association between parameters. The $p$ values of $<0.05$ were accepted as statistically significant, and $\mathrm{p}$ values lower than 0.001 were shown as $\mathrm{p}<0.001$.

\section{Results}

Baseline characteristics and biochemical test results of two groups were shown in Table 1. The mean ages of SCH group and the euthyroid group were $24.39 \pm 6.28$ and $23.92 \pm 5.86$ years, respectively $(\mathrm{p}=0.721)$. SCH group had numerically higher WBC, PLT, PCT, PLR, MPR and non-HDL levels than the euthyroid group but the differences were not statistically significant $(p>0.05)$. SCH group had lower MPV and PDW levels ( $p>0.05)$. The mean levels of MHR, NLR, TC/HDL cholesterol, TG/HDL cholesterol and LDL cholesterol/HDL cholesterol were statistically significantly higher in SCH group ( $\mathrm{p}<0.05)$ (Table 1).
Only MHR was significantly related with SCH in PCOS patients among the inflammatory markers group. Then, Spearman's correlation analysis was performed to evaluate the correlations between TSH levels and other biochemical parameters of SCH group. As a result, only TC/HDL cholesterol levels were statistically significantly and positively correlated with TSH levels of SCH group, among other atherogenic indices. TC/HDL cholesterol levels of SCH group were also statistically significantly correlated

Table 2: Spearman's correlations between TC/HDL-C and inflammatory markers in $\mathrm{PCOS}$ patients with $\mathrm{SCH}$ group.

\begin{tabular}{lrr}
\hline TC/HDL-C & \multicolumn{2}{c}{ PCOS patients with SCH } \\
\cline { 2 - 3 } & r value & p-Value \\
\hline WBC & 0.515 & 0.003 \\
PLT & 0.442 & 0.011 \\
PCT & 0.370 & 0.037 \\
PDW & 0.382 & 0.031 \\
MHR & 0.523 & 0.002 \\
MPR & -0.471 & 0.006 \\
NLR & 0.490 & 0.641 \\
TSH & 0.402 & 0.028 \\
\hline
\end{tabular}

WBC, White blood cell; PLT, platelet; PCT, plateletcrit; PDW, platelet distribution width; MHR, monocyte to high density lipoprotein ratio; MPR, monocyte to platelet ratio; NLR, neutrophyl to lymphocyte ratio; TSH, thyrotropin. r: Correlation coefficient, $p<0.05$ : Statistically significant. 
with inflammatory markers as WBC, PLT, PDW, PCT, MPR and MHR (Table 2).

\section{Discussion}

PCOS is a common endocrinopathy effecting reproductive age women [1]. Prevalence of dyslipidemia and SCH are the risk factors of metabolic and cardiac diseases are also higher in these patients. Therefore, we planned our study focusing on SCH in PCOS patients, its relations with atherogenic indices and also inflammatory markers, and its impact on these parameters.

Emerging studies had reported the SCH prevalence of PCOS patients and they also reported that PCOS might aggravate the SCH development [18]. In the study of Tagliaferri et al. it was indicated that obesity and insulin resistance, which are the parts of the pathogenesis of the disease, mediated this SCH development in PCOS patients [19]. Researchers also mentioned that serum TC and TG levels were higher in PCOS with SCH and PCOS is more likely to exhibit hyperlipidemia [20, 21]. They also concluded that compared to healthy populations, PCOS is related with high incidence of SCH [21]. Comply with the literature, in our study; we found lipid profile parameters and atherogenic indices were higher in SCH group of PCOS patients, too. TC/HDL cholesterol levels were statistically significantly and positively correlated with $\mathrm{SCH}$ group of PCOS patients. HDL cholesterol has anti-inflammatory, antioxidant, and antithrombotic effects [22], but monocyte has inflammatory and atherogenic effects [23]; so, MHR that combined the predictive efficacy of these two markers, monocyte and HDL, reflects the inflammatory situation.

Researchers discussed inflammation and immune system in PCOS, and they showed that low progesteron (low anti-inflammatory effect) and overstimulated estrogen levels (high immune-stimulatory effect) may cause autoimmunity and low-grade chronic inflammation [20]. Concordantly, in our study, we found higher inflammatory markers in SCH group, too. WBC, PLT, PCT, PLR and MPR levels were numerical, NLR and MHR levels were also statistically significantly higher in $\mathrm{SCH}$ group. To the best of our knowledge, this is the first study indicating mean MPR in PCOS patients in the literature.

In the long term, $\mathrm{SCH}$ might cause an increase in the risk of developing various cardiovascular comorbidities [21]. Therefore, greater awareness is needed for PCOS women with SCH.

Our study had some limitations. First, our sample size was relatively small. Second, it was a retrospective study so we couldn't get patients serum samples and we couldn't study other inflammatory markers or antibodies to diagnose autoimmune thyroiditis. So, further prospective studies with a larger sample size are needed to support our findings.

In summary, we deduced that serum TSH levels should be measured in PCOS patients with dyslipidemia. Screening thyroid hormones and maybe treating $\mathrm{SCH}$ in PCOS patients may lower their lipid levels and may also decelerate developing overt hypothyroidism.

Acknowledgments: Essential participation in the concept and design of the study were done by all authors.

Research funding: None declared.

Author contributions: All authors have accepted responsibility for the entire content of this manuscript and approved its submission.

Competing interests: Authors state no conflict of interest. Informed consent: Informed consent was not obtained from participants because of the retrospective design of the study.

Ethical approval: Approval was obtained prior to the study from Erciyes University Clinical Research Ethics Committee (2019/841).

\section{References}

1. Azziz R, Carmina E, Chen Z, Dunaif A, Laven JSE, Legro RS, et al. Polycystic ovary syndrome. Nature Rev Dis Primers 2016;2:16057.

2. Leon LIR, Mayrin JV. Polycystic ovarian disease (Stein-Leventhal syndrome). In: StatPearls [Internet]. Treasure Island (FL): StatPearls Publishing; 2020.

3. Dadachanji R, Shaikh N, Mukherjee S. Genetic variants associated with hyperandrogenemia in PCOS pathophysiology. Genet Res Int 2018;2018:7624932.

4. Rajska A, Buszewska-Forajta M, Rachón D, Markuszewski MJ. Metabolomic insight into polycystic ovary syndrome-an overview. Int J Mol Sci 2020;21:4853.

5. Chbat J, Ezzat S, Papi G. Subclinical hypothyroidism. Minerva Endocrinol 2020.https://doi.org/10.23736/S0391-1977.20. 03176-4. [Epub ahead of print].

6. Bedaiwy MA, Abdel-Rahman MY, Tan J, AbdelHafez FF, Abdelkareem AO, Henry D, et al. Clinical, hormonal, and metabolic parameters in women with subclinical hypothyroidism and polycystic ovary syndrome: a cross-sectional study. J Womens Health 2018;27:659-64.

7. Saadeh NA, Saadeh R, Rousan LA, Rawashdeh D, Obeidat A, Saadeh AM. Biochemical and ultrasound characteristics of subclinical hypothyroid patients in north of Jordan: who was treated? Int J Gen Med 2020;13:305-10.

8. Fatima M, Amjad S, Ali HS, Ahmed T, Khan S, Raza M, et al. Correlation of subclinical hypothyroidism with polycystic ovary syndrome (PCOS). Cureus 2020;12:e8142.

9. Goyal G, Goyal LD, Sheenam HS, Arora K, Kaur H. J subclinical hypothyroidism and associated cardiovascular risk factor in perimenopausal females. Midlife Health 2020;11:6-11. 
10. Escobar-Morreale HF. Polycystic ovary syndrome: definition, aetiology, diagnosis and treatment. Nat Rev Endocrinol 2018;14: 270-84.

11. Hueston WJ, Pearson WS. Subclinical hypothyroidism and the risk of hypercholesterolemia. Ann Fam Med 2004;2:351-5.

12. Cai J, Zhang Y, Wang Y, Li S, Wang L, Zheng J, et al. High thyroid stimulating hormone level is associated with hyperandrogenism in euthyroid polycystic ovary syndrome (PCOS) women, independent of age, BMI, and thyroid autoimmunity: a cross-sectional analysis. Front Endocrinol 2019;10:222.

13. Kałużna M, Człapka-Matyasik M, Wachowiak-Ochmańska K, Moczko J, Kaczmarek J, Janickiet A, et al. Effect of central obesity and hyperandrogenism on selected inflammatory markers in patients with PCOS: a WHtR-matched case-control study. J Clin Med 2020;9:E3024.

14. Usta A, Avci E, Bulbul CB, Kadi H, Adali E. The monocyte counts to HDL cholesterol ratio in obese and lean patients with polycystic ovary syndrome. Reprod Biol Endocrinol 2018;16: 34.

15. Cakiroglu Y, Vural F, Vural B. The inflammatory markers in polycystic ovary syndrome: association with obesity and IVF outcomes. J Endocrinol Invest 2016;39:899-907.

16. Rudnicka E, Kunicki M, Suchta K, Machura P, Grymowicz M, Smolarczyk R. Inflammatory markers in women with polycystic ovary syndrome. BioMed Res Int 2020;2020:4092470.
17. The Rotterdam ESHRE/ASRM-sponsored PCOS consensus workshop group. Revised 2003 consensus on diagnostic criteria and long-term health risks related to polycystic ovary syndrome (PCOS). Fertil Steril 2004;81:19-25.

18. Ding X, Yang L, Wang J, Tang R, Chen Q, Panet J, et al. Subclinical hypothyroidism in polycystic ovary syndrome: a systematic review and meta-analysis. Front Endocrinol 2018;9:700.

19. Tagliaferri V, Romualdi D, Guido M, Mancini A, Cicco SD, Florio CD, et al. The link between metabolic features and TSH levels in polycystic ovary syndrome is modulated by the body weight: an euglycaemic hyperinsulinaemic clamp study. Eur J Endocrinol 2016;175:433-41.

20. de Medeiros SF, de Medeiros MAS, Ormond CM, Barbosa JS, Yamamoto MMW. Subclinical hypothyroidism impact on the characteristics of patients with polycystic ovary syndrome. A meta-analysis of observational studies. Gynecol Obstet Invest 2018;83:105-15.

21. Yu Q, Wang JB. Subclinical hypothyroidism in PCOS: impact on presentation, insulin resistance, and cardiovascular risk. BioMed Res Int 2016;2016:2067087.

22. Haghikia A, Landmesser U. High-density lipoproteins: effects on vascular function and role in the immune response. Cardiol Clin 2018;36:317-27.

23. Cakir I, Cakir N, Atalay MA, Koc AN. Large unstained cells are correlated with inflammatory biomarkers in patients with invasive aspergillosis. Turk J Biochem 2018;43:306-11. 